\title{
Nanduty
}

ISSN:2317-8590

\section{Contornos das biografias de agentes envolvidos no trâmite da PEC 215}

\author{
Rayane B. Macedo - (rayane bartolini@ hotmail.com) \\ Simone Becker UFGD/MS-CNPq - (simonebk@yahoo.com.br)
}

\begin{abstract}
Resumo
A partir de pesquisas complementares entre si, o presente ensaio volta-se à descrição genealógica (das biografias) dos parlamentares envolvidos no trâmite da PEC 215. Em meio às tessituras das biografias nota-se a prevalência e a capilaridade dos agentes da bancada ruralista na gest(aç)ão das alterações no processo demarcatório de terras indígenas. O processo demarcatório tende - se a PEC 215 for aprovada - a se deslocar do Executivo para o Congresso Nacional. Enfim, os entrelaçamentos entre os parlamentares da bancada ruralista com as outras principais bancadas, suscita o quão transpartidárias são estas movimentações.
\end{abstract}

Palavras-chaves: biografias - bancada ruralista - PEC 215

\section{Biographies' contours of agents involved in the PEC 215 process}

\begin{abstract}
Based on complementary researches, the present essay turns to the genealogical description (of the biographies) of the parliamentarians involved in the process of the PEC 215. In the midst of the biographies, we can see the prevalence and capillarity of ruralist bench agents on the management of changes in the demarcation process of indigenous lands. The demarcation process tends -whether the PEC 215 to be approved - to move from the Executive to the National Congress. Finally, the interweaving between the parliamentarians of the ruralist group and the other main groups, raises how (trans)party these movements are.
\end{abstract}

Keywords: biographies - ruralist bench - PEC 215 


\section{Notas preliminares}

A Constituição Federal de 1988 no artigo $231^{1}$ garante aos povos indígenas o direito às suas terras tradicionais. Entretanto, mesmo o reconhecimento constitucional do direito às terras tradicionais sendo uma conquista indígena e haver no Brasil mais de 240 etnias que somam 896.917 pessoas (PIB.SOCIOAMBIENTAL, 2018), ainda existem muitas terras a serem demarcadas. A dificuldade nesse processo de demarcação se desenrola não apenas com relação à demora do processo burocrático, mas principalmente, devido aos conflitos engendrados com o interesse do setor rural ou do agronegócio. Essa articulação do setor rural ocorre por meio de grupo pluripartidário composto atualmente por mais de 200 parlamentares, conhecido também como Bancada Ruralista ou Frente Parlamentar da Agropecuária (FPAGROPECUARIA, 2018).

Cabe ressaltar que esses conflitos são materializados no dia-a-dia, por exemplo, tanto na produção de discursos de ódio por parte da mídia (ABREU, 2017; LANDA, 2018) quanto

\footnotetext{
${ }^{1}$ Dispõe o artigo 231 da CF/88:

São reconhecidos aos índios sua organização social, costumes, línguas, crenças e tradições, e os direitos originários sobre as terras que tradicionalmente ocupam, competindo à União demarcá-las, proteger e fazer respeitar todos os seus bens.

$\S 1^{\circ}$ São terras tradicionalmente ocupadas pelos índios as por eles habitadas em caráter permanente, as utilizadas para suas atividades produtivas, as imprescindíveis à preservação dos recursos ambientais necessários a seu bem-estar e as necessárias a sua reprodução física e cultural, segundo seus usos, costumes e tradições.

$\S 2^{\circ}$ As terras tradicionalmente ocupadas pelos índios destinam-se a sua posse permanente, cabendo-lhes o usufruto exclusivo das riquezas do solo, dos rios e dos lagos nelas existentes.

$\S 3^{\circ} \mathrm{O}$ aproveitamento dos recursos hídricos, incluídos os potenciais energéticos, a pesquisa e a lavra das riquezas minerais em terras indígenas só podem ser efetivados com autorização do Congresso Nacional, ouvidas as comunidades afetadas, ficando-lhes assegurada participação nos resultados da lavra, na forma da lei.

$\S 4^{\circ}$ As terras de que trata este artigo são inalienáveis e indisponíveis, e os direitos sobre elas, imprescritíveis.

$\S 5^{\circ}$ É vedada a remoção dos grupos indígenas de suas terras, salvo, "ad referendum" do Congresso Nacional, em caso de catástrofe ou epidemia que ponha em risco sua população, ou no interesse da soberania do País, após deliberação do Congresso Nacional, garantido, em qualquer hipótese, o retorno imediato logo que cesse o risco.

$\S 6^{\circ}$ São nulos e extintos, não produzindo efeitos jurídicos, os atos que tenham por objeto a ocupação, o domínio e a posse das terras a que se refere este artigo, ou a exploração das riquezas naturais do solo, dos rios e dos lagos nelas existentes, ressalvado relevante interesse público da União, segundo o que dispuser lei complementar, não gerando a nulidade e a extinção direito a indenização ou a ações contra a União, salvo, na forma da lei, quanto às benfeitorias derivadas da ocupação de boa fé.

$\S 7^{\circ}$ Não se aplica às terras indígenas o disposto no art. $174, \S 3^{\circ}$ e $\S 4^{\circ}$. (PLANALTO, 2018).
} 
na violência que leva ao etnocídio (VIVEIROS DE CASTRO, 2016). A cidade de Dourados (MS) ilustra este palco conflituoso. O espraiamento dos produtores rurais e seus ditames são figurinhas marcadas no álbum da árida cidade, assim como, a monotemática das monoculturas que fazem girar as máquinas registradoras dos números por eles amealhados. Desde 2008, testemunhamos visualmente os enunciados anunciando (in)diretamente pelas ruas douradenses, em faixas e/ou adesivos de caminhonetes, as reiterações do lema da "produção sim, demarcação não" (SILVA, 2013: 24). No prefácio à obra "A queda do céu”, Eduardo Viveiros de Castro (2015: 18), problematiza essa paisagem que abriga os bois da cerca pra dentro e os indígenas da cerca pra fora, sob uma lógica que dizima a res publica (ou República), para cada vez mais dar pasto a "211 milhões de bois (hoje mais numerosos que nossa população de humanos)".

Muitas das terras indígenas no Estado de Mato Grosso do Sul foram ocupadas por não indígenas (LENHARO, 1986), que atualmente acaba sendo um dos disparadores dos conflitos agrários que dão o tom das cotidianas guerras etnocidas na e da Região (VIVEIROS DE CASTRO 2016; CUNHA 2009). Conflitos estes que cada vez mais se intensificam, gerando mortes (literais para além das sociais), principalmente daquelas vidas vivas que são ainda mais precarizadas por parte do Estado (BUTLER 2015), porque desimportantes ou abjetas como as dos indígenas ${ }^{2}$ (BECKER e ROCHA, 2017; BECKER, OLIVEIRA e MARTINS, 2016). Em meio a este contexto de conflitos e buscas por soluções destaca-se a Proposta de Emenda à Constituição 215, ou como também é chamada a "PEC das demarcações".

A PEC 215 em tramitação desde 2000 no Congresso Nacional propõe mudanças no processo de demarcação de terras, sendo seu principal propulsor o senhor Almir de Morais Sá, na época deputado federal de Roraima pelo Partido Progressista Brasileiro (PPB).

Em sua primeira redação, a citada emenda constitucional propôs mudanças que

\footnotetext{
${ }^{2}$ A finitude de nossa vida com a certeza do evento morte faz com que todas as vidas vivas gozem de dada precariedade. Entretanto, como bem nos inspira Judith Butler em "Quadros de Guerra" (2015) e nos trabalhos voltados às discussões de vidas precárias e inumanas, há por parte dos Estados (Nacionais) e suas respectivas instituições, movimentos constantes de acentuação quanto à precarização ainda maior de dadas vidas que não importam. Algo, a nosso ver, indissociável das discussões contemporâneas sobre biopolítica foucaultiana e seus efeitos cada vez mais voltados ao fazer morrer como prerrogativa dos racismos estatais. Eis a noção de necropolítica em Achille Mbembe (2016).
} 
incidem basicamente em três pontos no processo de demarcação: primeiro atribui como competência exclusiva do Congresso Nacional a aprovação da demarcação de terras indígenas, ao invés de sê-la como hoje competência do Poder Executivo; segundo faz a ratificação de terras já homologadas, podendo implicar na retificação de decisões anteriores e, o terceiro ponto estabelece que os critérios de demarcação sejam definidos por lei ordinária, o que atualmente é estabelecido por decreto via Poder Executivo, implicando em dificuldades de ulteriores modificações. Portanto, todas essas alterações tendem a beneficiar os produtores rurais e suas demandas capitalísticas ${ }^{3}$ (GUATTARI, 1985).

Após passar pela fase de análise de conteúdo desenvolvido pela Comissão Especial ${ }^{4}$, o relatório final - cujo relator foi o então deputado Osmar Serraglio - trouxe relevantes modificações em seu texto inicial. Destacamos as que seguem: a indenização em dinheiro ao proprietário de "boa-fé"; a produção de políticas especiais de saúde, educação e previdência social voltadas aos indígenas ${ }^{5}$ e a possibilidade do Estado (União) explorar as terras se for de seu interesse, seja para construir ferrovias, hidrovias, edificações etc.; a inserção de forças militares e policiais sem consulta ("prévia" ${ }^{6 ")}$ às comunidades em seus territórios, bem como a possibilidade de arrendar a terra demarcada, e, finalmente, a livre presença e moradia de nãoindígenas em áreas demarcadas (MACEDO, 2017).

Em síntese, neste ensaio mapeamos os agentes envolvidos, suas biografias (BOURDIEU, 2001) e respectivos partidos "únicos” (CAPIBERIBE \& BONILLA 2015: 296) que compõem de forma direta (através de votos e relatórios)o processo de trâmite da PEC 215 - ou "PEC da Demarcação". Para isso, partindo da ferramenta conceitual do rizoma (DELEUZE \& GUATTARI, 1995), resgatamos o contexto e consequente capilaridade da Bancada Ruralista (ou do Agronegócio) no cenário nacional, e, por conseguinte, da PEC. Nas reticências finais, ao arrepio das conclusões, suscitamos os agenciamentos e protagonismos do movimento indígena num projeto de emenda que os invisibiliza, e a despeito disso, seu

\footnotetext{
${ }^{3}$ Félix Guattari (1985: 212) explorará o Capital Integrado Mundial (CMI) para esmiuçar o quanto o capitalismo é rizomático, isto é, está capilarizado em todas as esferas sociais. Nesse sentido, o que há é uma "mundialização da divisão do trabalho" ao invés de uma "divisão internacional do trabalho", pois aquela se refere aos tipos de performances que extrapolam os modos de produção capitalistas.

${ }^{4}$ Uma das fases do processo de tramitação de mudanças constitucionais em solos brasileiros.

${ }^{5}$ Para maiores esclarecimentos sobre a Proposta de alterações das leis previdenciárias, sugerimos a leitura do artigo "O (re)torno da guerra justa(?) de Simone Becker e Valentin Ferreira Moraes (2017).

${ }^{6}$ A respeito da importância da consulta prévia e seus (des)respeitos por parte do Estado brasileiro são fundamentais as costuras tecidas por Luíza Meyer em sua pesquisa (2014).
} 


\section{Nanduty}

ISSN:2317-8590

trâmite conta com reflexos de suas capilaridades, como as suspensões de votações frente às mobilizações presenciais em Brasília.

\section{Contextualizações acerca da Bancada Ruralista}

Ao analisarmos a formação e estabelecimento da Bancada Ruralista é possível traçar seus processos de (des)continuidades, quiçá face à sua capilaridade (rizomática), levando em conta sua influência no cenário do Legislativo brasileiro, como já expusemos anteriormente. Criada em 1985, à época era denominada de União Democrática Ruralista (UDR), tendo como seu fundador e principal expoente Roberto Caiado - político filiado ao PFL (atual DEM), também médico e de família de produtores rurais. Participante do processo de desenvolvimento da Constituição de 1988, a UDR tinha como principal papel fazer oposição à reforma agrária e combater a ocupação de terras por trabalhadores rurais (VIGNA, 2001).

Em pesquisa ao Instituto de Estudos Socioeconômicos (INESC), o historiador Edélcio Vigna fez uma análise sobre a Bancada Ruralista, observando a atuação desta na Câmara dos Deputados. Vigna (2001) aponta que se num primeiro momento, ainda enquanto UDR, a bancada tinha força de mobilização, num segundo momento, em 1992 a UDR (que não se distinguia da Bancada ruralista) foi perdendo espaço e influência. Este declínio se deu tanto por conta do seu teor mais agressivo - liderado por Roberto Caiado (PFL), quanto pela desarticulação nacional das forças conservadoras. Ambos, nesse período, contribuíram para a perda de sua referência de representação.

As divergências fragmentaram os ruralistas e dificultaram suas atuações. A desarticulação do movimento facilitou, por exemplo, a regulamentação da reforma agrária no Congresso que se deu apenas cinco anos após a vigência da Constituição Federal Brasileira de 1988, ou seja, em 1993. Graças a essa desarticulação, problemas judiciais e acusações de incentivo às atividades paramilitares contra o MST (Movimento dos Trabalhadores Sem Terra) levaram ao "fim" da UDR e suas atividades. Foi no final dos anos de 1990 se destacando em confrontos com o MST (Movimento dos Trabalhadores Sem Terra) que o movimento ressurge.

Outra questão interessante apontada na pesquisa de Vigna foi a realização de um mapeamento da profissão dos sujeitos que fazem parte da Bancada Ruralista nos anos de 1994 a 2001. Notou-se que além da carreira política, muitos têm pelo menos duas profissões como: 
agropecuarista e advogado; agropecuarista e médico; agropecuarista e comerciante. Tal fato mantem-se até os dias atuais, influenciando no posicionamento perante algumas discussões, como em relação à produção de transgênicos, no qual os médicos tendem a ser contrários ${ }^{7}$.

Entre os anos de 1995 a 1998, notou-se uma necessidade de mudança, assim o grupo ruralista acabou passando por uma reestruturação. De acordo com Vigna (2001: 11):

Pode-se dizer que houve uma distribuição de responsabilidades quanto à articulação no Parlamento e na sociedade. Os parlamentares identificados com os diferentes setores produtivos assumiram obrigações de articular esses interesses: agricultores familiares, agroindustriais, pecuaristas, empresários rurais. Essa divisão de trabalho qualificou o grupo.

Dessa forma, os ruralistas foram se organizando estrategicamente e ampliando seu cenário de atuação, ou seja, espraiando suas presenças em estruturas de poder no tocante à microfísica de seus exercícios. Mas foi apenas em 2002 que os ruralistas se consolidaram enquanto uma Bancada, sendo assim, foi criada a Frente Parlamentar de Apoio à Agropecuária.

Em 2008, houve uma mudança passando a citada bancada a ser denominada Frente Parlamentar da Agropecuária (FPA), justamente para que ela se adequasse às regras de regulamentação criadas pela Câmara dos Deputados. Para que fossem feitos registros de frentes parlamentares, passou-se a exigir a assinatura de pelo menos um terço do Poder Legislativo Federal, além de que deveria ser integrada de forma suprapartidária/transpartidária $^{8}$ e destinar-se a promover o aprimoramento da legislação federal sobre determinado setor da sociedade.

\footnotetext{
${ }^{7}$ Ricardo Costa de Oliveira (2007: 150) inspira-nos com sua genealogia produzida sobre certas famílias, seus respectivos interesses/riquezas e suas (des)continuidades no poder do estado do Paraná, a pensarmos tais entrelaçamentos como uma "rede política". Esta consiste numa "conexão de interesses envolvendo empresários e cargos políticos no aparelho de Estado em diferentes poderes, no executivo, legislativo e no judiciário, e em outros espaços de poder em função de operações de mútuo benefício e ações político-financeiras articuladas na informalidade",

8 A expressão "suprapartidária" é uma noção própria do contexto de regras para a formação de Frentes Parlamentares, sendo utilizada para explicitar que as Frentes devem ser compostas por vários partidos, sem que se subordine a nenhum deles. Outra regra é ter pelo menos 1/3 dos integrantes do Poder Legislativo Federal e ter por objetivo aprimorar a legislação referente a um tema específico, ou seja, são grupos institucionalizados que tem o período de duração de uma legislatura, mas posteriormente podem se renovar. Assim, o termo "transpartidária" foi aqui cunhado pelas autoras (por vezes utilizaremos ao longo do texto ao invés de suprapartidárias), porque estas movimentações atravessam e são (retro)alimentadas pelas dinâmicas que são também as dos partidos políticos. O prefixo "trans" para além de significar "através", também sinaliza para o "transbordar". Portanto, ambos aqui se complementam.
} 


\section{Nanduty}

ISSN:2317-8590

Assim, em seu próprio site, a FPA (www.fpagropecuaria.org.br) atualmente descreve enquanto objetivo do grupo, estimular a ampliação de políticas públicas para o desenvolvimento do agronegócio nacional. Aponta como prioridades atuais a modernização da legislação trabalhista, fundiária, tributária, além da regulamentação da questão de terras indígenas e áreas de quilombolas, para garantir a segurança jurídica necessária à competitividade do setor (FPAGROPECUARIA 2018). Nesse sentido, a atual reforma da previdência com discursos que condicionam tanto o bolsa família quanto à extinção da categoria de segurado especial convergem para as plataformas do agronegócio.

Após o golpe de 2016 travestido de impeachment, a Bancada Ruralista conseguiu $\begin{array}{llll}\text { ocupar nichos do aparelho } & \text { certos }\end{array}$ do Estado, onde exerce o seu "poder de mando legitimado", como no Ministério da Agricultura, o qual atualmente é presidido por Blario Maggi (PP-MT), também conhecido como o "rei da soja" e recentemente denunciado por corrupção pela Procuradoria Geral da República (UOL, 2018). Na Comissão de Agricultura e Política Rural da Câmara dos Deputados há a presidência de Lázaro Botlheo (PP-TO) que é empresário e pecuarista. E no Ministério da Justiça, Osmar Serraglio (PMDB-PR), das bancadas contra o aborto, evangélica, do agronegócio, dentre outras com hegemonia no atual contexto, ficou durante um pouco mais de dois meses, sendo sucedido por Torquato Jardim (CARTA CAPITAL, 2018). Percebamos como os interesses entre as Bancadas se tocam e se atravessam, seja a Evangélica, seja a de Parentes, seja a de Empreiteiras/Construtoras, seja a Ruralista, seja a Empresarial.

Nos últimos anos, a Bancada Ruralista também tem "formalizado" suas críticas à Funai e às Ong's através do desencadeamento de CPI’s (Comissão Parlamentar de Inquérito) que são investigações conduzidas pelo Poder Legislativo, como aquelas contra a Funai, o Incra, e o CIMI. Com relação à CPI do CIMI, o foco da investigação apontado em relatório foi a "atuação do Conselho Indigenista Missionário (CIMI) em atos de incitação e financiamento de invasão de propriedades particulares por indígenas no Mato Grosso do Sul” (AL.MS 2017: 6). O relatório final foi aprovado e encaminhado aos órgãos responsáveis e envolvidos com a questão indígena, dentre eles o Vaticano, já que o CIMI é ligado à Igreja Católica. Ronaldo de Almeida (2017: s/p) ao cartografar a composição partidária e os movimentos da Bancada Evangélica (ou Frente Parlamentar Evangélica) junto à Câmara dos 


\section{Nanduty}

ISSN:2317-8590

Deputados, suscita com suas tessituras alguns dos interesses de seus membros com as questões indígenas e com aquelas neoliberais.

O então presidente da Câmara dos Deputados, Eduardo Cunha, foi protagonista na aprovação, em primeira instância, do Projeto das Terceirizações, que contou com o voto da Frente Parlamentar Evangélica. Ou, ainda, vale citar a disputa do PSC pela FUNAI, órgão federal central no processo de demarcação de terras indígenas e quilombolas. Na CPI da FUNAI-INCRA, na Câmara dos Deputados, a Frente Parlamentar Evangélica operou como linha auxiliar da denominada bancada do agronegócio e da mineração em oposição aos que milita pelos direitos dos indígenas, sobretudo, à terra (ALMEIDA, 2017: s/p). (Destaques nossos).

Sobre a CPI da Funai e do Incra que visam investigar atos das instituições durante o governo PT (Partido dos Trabalhadores), salientamos que ela gerou desdobramentos importantes, tal como expõe em entrevista ao site de notícias UOL, em janeiro de 2016, o então presidente da Funai, João Pedro Gonçalvez:

Nós também estamos sendo alvo de uma CPI (Comissão Parlamentar de Inquérito). Os povos indígenas estão vivendo esse constrangimento da CPI. A CPI não diz respeito a recursos financeiros. Ela ataca antropólogos, os relatórios, a terra indígena. Ao mesmo tempo em que tramitam no Congresso várias PECs propondo retrocessos, existe uma CPI contra o Incra e a Funai (UOL 2016: s/p).

Em entrevista, o então presidente da FUNAI Gonçalvez aponta ainda que os setores com interesse na CPI são os ruralistas. Declarou que a CPI seria uma forma de "criar uma situação para viabilizar a PEC 215 para levar ao Congresso a definição das terras indígenas" (UOL 2016: s/p.) Ou seja, a criação da CPI, impulsionada por ruralistas acaba também por ser uma forma de questionar a legitimidade da Funai, criando discursos deslegitimadores de antropólogos e relatórios sob a chancela da "criminalidade". Há que se destacar o tom de criminalização do CIMI decorrente da CPI da Funai em $2017^{9}$.

Cremos que tais discussões podem ser atreladas à criminalização dos movimentos sociais no Brasil, coincidentemente após promulgação da lei antiterrorismo no Brasil (13260/2016). Em 2016 após o Golpe veio à tona no cenário do Congresso, o PLS 272/2016, que tenta reintroduzir parte vetada pela então presidenta Dilma Rousseff, na lei antiterrorismo, acerca da possibilidade de incriminação de manifestações de movimentos

\footnotetext{
9 - A CPI que durou de 2016 a 2017 terminou com o pedido de indiciamento de 67 pessoas (AGENCIA BRASIL, 2018).
} 
sociais. Cabível nos atentarmos para os compartilhares de Judith Butler (2018) quanto à criminalização do conhecimento, e então na inspiração que seu artigo nos traz para refletir sobre questões que tocam as ciências humanas mundo afora e adentro. Nas diferenças e convergências entre liberdade acadêmica e de expressão, tanto as universidades quanto os Estados democráticos deveriam escorregar aos docentes/pesquisadores suporte para as suas posições de cunho político, extra e intramuros acadêmicos. De cunho político porque não há conhecimento nas ciências humanas que não toque (in)diretamente questões estruturantes das sociedades democráticas.

Embora a liberdade acadêmica e a liberdade de expressão política não sejam a mesma coisa, punir acadêmicos por seu poder político real ou imaginário nos diz algo sobre o papel das universidades na vida democrática. As universidades produzem ideias que têm vida própria; a livre circulação dessas ideias faz parte da cultura política democrática e a proteção dessa circulação é uma obrigação das sociedades democráticas. Talvez a forma estruturada de conflito que define a liberdade acadêmica implique uma concepção mais ampla de como abordar a resolução de conflitos em outros domínios. Acadêmicos invariavelmente discordam e sua discordância é crucial para o crescimento de novos campos e novos conhecimentos. Cultivar formas produtivas de conflito é o que procuramos fazer tanto dentro dos muros da universidade, quanto buscamos conhecimento, quanto fora desses muros, à medida que nos engajamos em promover práticas democráticas de debate e contestação na esfera pública (BUTLER, 2018: s/p).

Essa (re)produção de discursos legitimados por parte do setor agro que deslegitimam devires outros, capilariza-se de diversas formas, a saber: através de associações, tal como a Acrissul (Associação dos Criadores de Mato Grosso do Sul); dos sindicatos regionais; e por meio da promoção de eventos como a Expoagro que ocorre em diversas cidades em todo país. Tais discursos mantêm também espaço em diversas mídias, como sites, jornais impressos e canais de TV. Dentre os canais específicos destaca-se o Canal do Boi e o Canal Rural. Igualmente se articulam através do apoio de canais abertos, como a Rede Globo, que como ilustração, recentemente lançou uma propaganda que diz "Agro é tech, agro é pop, agro é tudo" (G1 2018a: s/p). Todos esses espaços se conectam, compondo uma espécie de rede onde discursos de poder são disseminados e (re)produzidos.

Cada vez mais a (retro)alimentação da estrutura golpista se faz, como sugere Suely Rolnik (2018) via estratégias "midiático-jurídica-parlamentar". Aqui nos detemos na noção do "rizoma" como uma ferramenta interessante na compreensão desse cenário. De acordo com a botânica, o rizoma é um caule subterrâneo que parece (não sendo) uma raiz, com 
capacidade de se espraiar de forma múltipla a(té) gerar outra planta. Observemos a "tiririca" como um exemplo de rizoma:

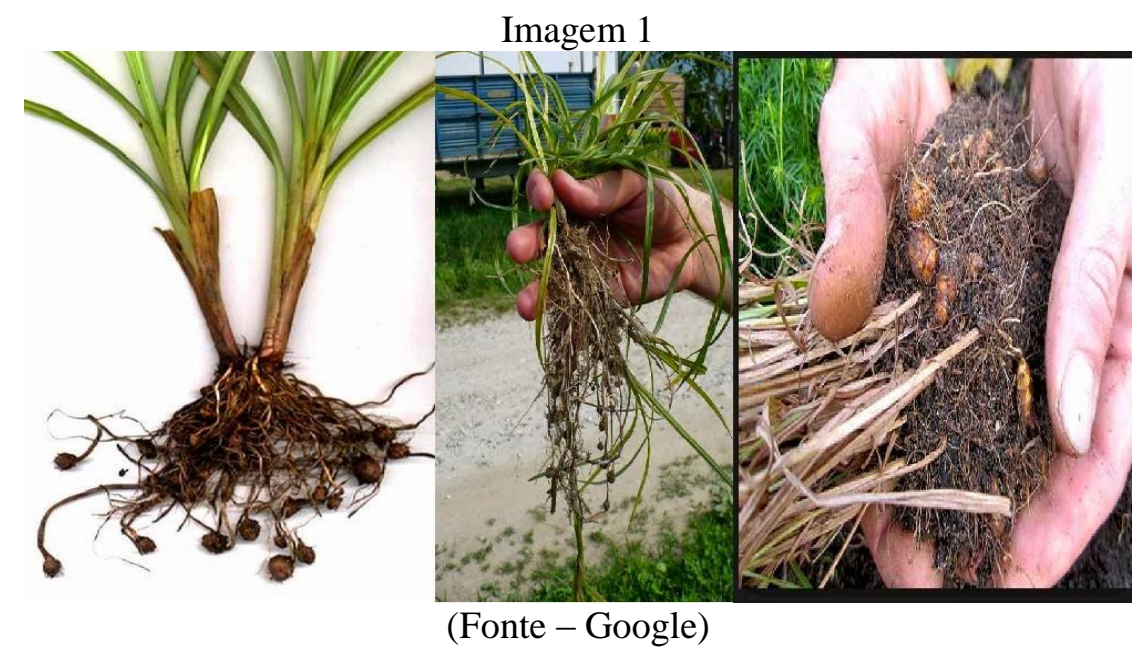

Deleuze e Guatarri (1995) inspirados neste conceito da botânica tece(ra)m suas (des)pensações sobre o rizoma: "ele (rizoma) não é feito de unidades, mas de dimensões, ou antes, de direções movediças. Ele não tem começo nem fim, mas sempre um meio pelo qual cresce e transborda" (DELEUZE; GUATTARI, 1995: 15).

Propositadamente ilustramos o rizoma $\operatorname{com}(\mathrm{o})$ a "praga" da "tiririca" $"$. A tiririca cabe aqui como ilustração de rizoma, haja vista que ela se espalha, infestando agriculturas, comprometendo a qualidade do solo. Por tais características, acabam possibilitando uma interessante analogia com a capilarização e articulação de discursos produzidos pela Bancada Ruralista e dispersados de inúmeras maneiras nefastas. Seus efeitos são nocivos não só para o solo, afinal defendem políticas de desmatamento e agrotóxicos, mas também para a própria vida, considerando toda a complexa guerra cotidiana dos etnocídios das populações indígenas.

Dentro deste contexto podemos notar que a terra é a temática que engloba estes sujeitos indígenas e ruralistas, sendo que a figura do Estado aparece enquanto o legitimador de discursos com sua presença ausente. Assim,

As terras indígenas fazem parte de um quadro mais amplo de disputas envolvendo a questão fundiária, que opõe, de um lado, não exatamente de maneira orgânica, o agronegócio, a mineração, as políticas de desenvolvimento econômico do Estado,

\footnotetext{
${ }^{10}$ Agradecemos (uma vez mais), o comentário e sugestão feitos por Célia Foster sobre a correlação da tiririca como rizoma.
} 
gestores públicos ligados ao setor agrícola e mineral; e, de outro, populações indígenas, quilombolas, populações tradicionais (caboclos, ribeirinhos, seringueiros, castanheiros), ambientalistas, antropólogos e indigenistas com diversas formações e origens (CAPIBERIBE \& BONILLA 2015: 295).

Assim, é possível notar suas características rizomáticas, ou seja, seu descentramento, sua multiplicidade, conexões e heterogeneidade. É por isso que o discurso ruralista (contra a demarcação) não está só dentro do Congresso (e nem se legitima só por este), mas também está na TV, nas músicas, nos preconceitos contra indígenas travestidos de piadas, ou seja, é disseminado de diversas formas em várias intensidades de poder. Da mesma forma que este discurso se dissemina ele também gera a resistência indígena que se organiza de forma capilarizada seja entre si, ou em parceria com ONG's, com a ONU, com a Igreja, utilizando redes socais, etc. Por sua vez, essa articulação indígena também reflete na articulação ruralista.

\section{Cercando a PEC215: mapeando as biografias que movimentam "o trâmite" do} sistema

De forma a dar sequência ao que até então expusemos, este item trará alguns aspectos da biografia dos agentes que permeiam o trâmite da PEC215 no que se referem a sua movimentação, seja através de votos ou relatórios. Assim, tal como o sociólogo Glauber Rocha Xavier costura em seu artigo "Senhores da Lei, Donos da Terra: o arauto da bancada ruralista na Câmara dos Deputados (2009-2014)", o levantamento biográfico é importante, pois:

Antes de se proceder a qualquer exercício sociológico de apreensão de discursos, é fundamental que se compreenda o agente social que os emite. Assim, cabe apresentar não apenas aquilo que se diz mas também quem diz, o contexto social que este agente está inserido, sua biografa e especialmente o grupo social a que pertence e quais interesses representa (XAVIER 2015:134).

Por isso, as biografias aqui descritas são baseadas no próprio sítio da Câmara dos Depurados, objetivando,

a compreensão da representação que se pretende do personagem político, seus principais atributos e os elementos constitutivos de sua biografa que legitimam sua atuação parlamentar" (XAVIER 2015:135).

Mapearemos sujeitos e exercícios de poderes, de modo a observar as interconexões que se estabelecem, ou seja, perceberemos as esferas de redes de poderes a partir das quais se 


\section{Nanduty}

ISSN:2317-8590

encontram estes agentes e como atuam em meio a estas. Assim, ao bebermos na noção de rizoma, apreendemos as biografias como feixes relacionais à la Bourdieu (2001), cujos enunciados falam menos dos "indivíduos" que os anunciam e mais do campo de forças e disputas nas quais estão enredados. Afinal ou no final das contas, lembremos que somos (re)produzidos performaticamente pelos discursos que nos instituem (BUTLER, 2003).

Feitas tais considerações, observemos o esquema abaixo:

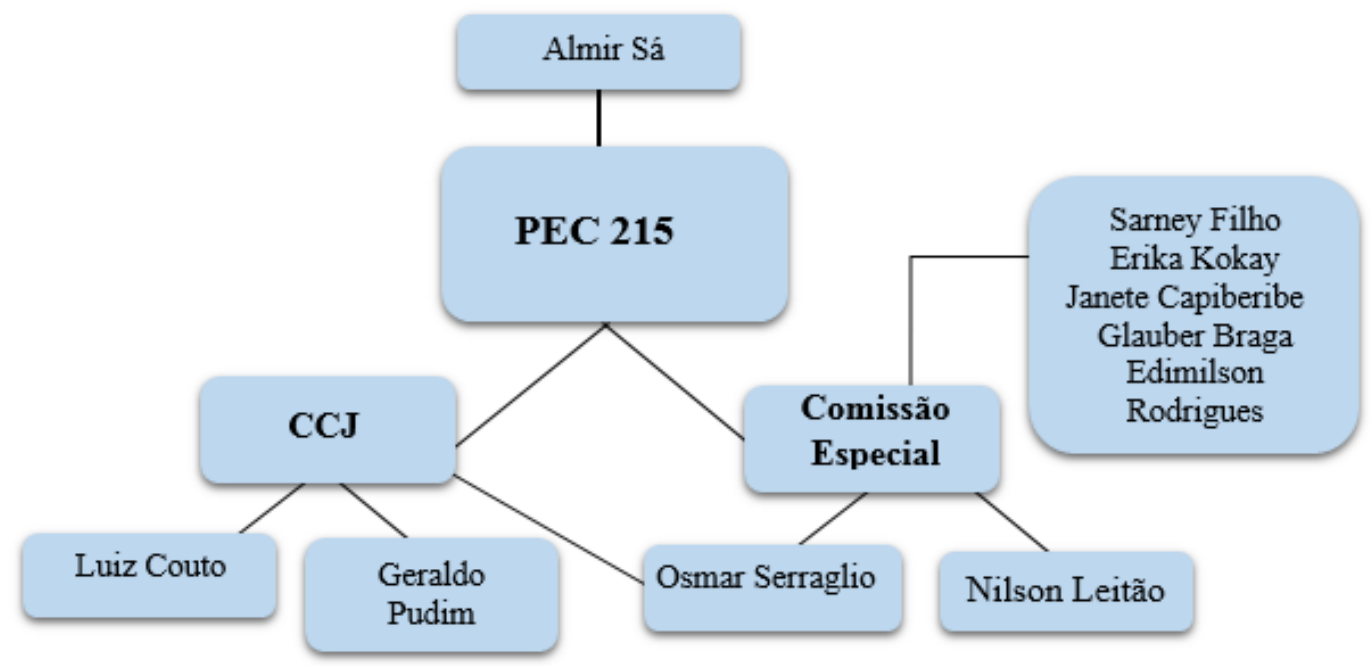

Os sujeitos que fazem parte deste mapeamento s(er)ão: Almir Morais Sá, propositor da PEC215; Luiz Couto e Geraldo Pudim relatores das CCJs (Comissão de Constituição e Justiça) - responsáveis pela análise da procedência legal do projeto de lei; Osmar Serraglio também relator de uma das CCJs e relator da Comissão Especial; Nilson Leitão que foi o presidente da Comissão Especial e, os cinco (5) autores dos votos em separado contra a PEC215, a saber: Sarney Filho, Janete Capiberibe, Erika Kokay, Glauber Braga e Edimilson Rodrigues. Para além desses parlamentares destacaremos alguns apontamentos acerca das características de maior relevância dos 22 (vinte e dois) membros que compõem a Comissão Especial da PEC215. Comecemos visualizando na tabela abaixo uma perspectiva mais ampliada sobre os membros da Comissão Especial: 
Tabela 1. Membros da Comissão Especial da PEC215

\begin{tabular}{|c|c|}
\hline TITULAR & SUPLENTE \\
\hline \multicolumn{2}{|c|}{ PT } \\
\hline Afonso Florence PT/BA (305-IV) & Dalva Figueiredo PT/AP (0-0) \\
\hline Geraldo Simóes PT/BA (0-0) & Padre Ton PT/RO (0-0) \\
\hline Padre Joâo PT/MG (743-IV) & Valmir Assunçáo PT/BA (739-IV) \\
\hline \multicolumn{2}{|c|}{ PMDB } \\
\hline Alceu Moreira PMDB/RS (238-IV) & Amir Lando PMDB/RO (0-0) - vaga do PSC \\
\hline Darcisio Perondi PMDB/RS (518-IN* & Celso Maldaner PMDB/SC (311-IV) \\
\hline \multirow[t]{2}{*}{ Osmar Serraglio PMDB/PR (845-IVk } & Marinha Raupp PMDB/RO (614-IV) \\
\hline & 1 vaga(s) \\
\hline \multicolumn{2}{|c|}{ PSDB } \\
\hline Nilson Leitáo PSDB/MT (825-IV) * & Domingos Sávio PSDB/MG (345-IV) \\
\hline Reinaldo Azambuja PSDB/MS $(0-0)_{*}$ & Raimundo Gomes de Matos PSDB/CE (725-IV) \\
\hline \multicolumn{2}{|r|}{ (1) } \\
\hline Junii Abe PSD/SP (0-0) & Eliene Lima PSD/MT (0-0) \\
\hline Moreira Mendes PSD/RO (0-0) & Marcos Montes PSD/MG (334-IV) \\
\hline \multicolumn{2}{|l|}{ (2) } \\
\hline Arthur Lira PPIAL(942-IV) & Carlos Magno PP/RO (0-0) \\
\hline Luis Carlos Heinze PP/RS (526-IM) & Dilceu Sperafico PPIPR (746-IV) \\
\hline \multicolumn{2}{|l|}{ Toninho Pinheiro PP/MG (584-III) - vaga do PTd"̈B } \\
\hline \multicolumn{2}{|l|}{ 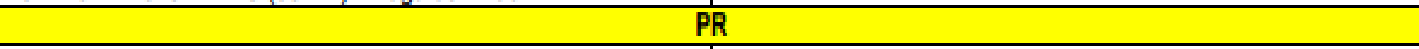 } \\
\hline \multirow[t]{2}{*}{ Giacobo PR/PR (762-II) } & Bernardo Santana de Vasconcellos PR/MG (0-0) - vaga do PTdoB \\
\hline & Luciano Castro PR/RR (0-0) \\
\hline \multicolumn{2}{|c|}{ PSB } \\
\hline Janete Capiberibe PSB/AP (209-IM) & Glauber Braga PSB/RJ (362-IV) \\
\hline \multicolumn{2}{|l|}{ 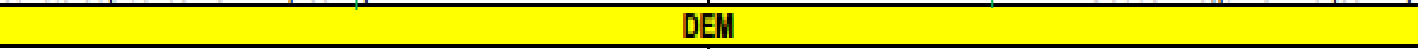 } \\
\hline Lira Maia DEM/PA $(0-0)$ & Mandetta DEM/MS (577-III) \\
\hline \multicolumn{2}{|c|}{ PDT } \\
\hline Giovanni Queiroz PDT/PA (0-0) & Oziel Oliveira PDT/BA $(0-0)$ \\
\hline \multicolumn{2}{|l|}{ 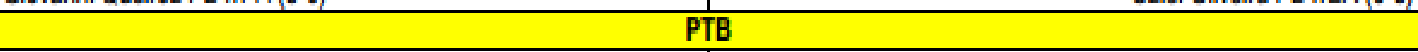 } \\
\hline Sabino Castelo Branco PTB/AM (0-0) & Nelson Marquezelli PTB/SP (920-IV) \\
\hline \multicolumn{2}{|c|}{ Bloco PV, PPS } \\
\hline Samey Filho PVIMA (202-14) & Penna PVISP $(0-0)$ \\
\hline \multicolumn{2}{|c|}{ PSC } \\
\hline Nelson Padovani PSC/PR (0-0) & (Deputado do PMDB ocupa a vaga) \\
\hline \multicolumn{2}{|c|}{$\frac{1}{\text { PCdoB }}$} \\
\hline Perpétua Almeida PCdoB/AC $(0-0)$ & Evandro Milhomen $\mathrm{PCdoB} / \mathrm{AP}(0-0)$ \\
\hline \multicolumn{2}{|c|}{ PTdoB } \\
\hline (Deputado do PP ocupa a vaga) & (Deputado do PR ocupa a vaga) \\
\hline Número de membros: 21 & Maioria Absoluta: 11 \\
\hline
\end{tabular}

\section{Legenda:}

*Frente Parlamentar da

Agropecuária

+ Frente Parlamentar em Apoio aos

Povos Indígenas 


\section{Nanduty}

ISSN:2317-8590

A tabela acima mostra os membros que compuseram a Comissão Especial da PEC215, que como suscitado foi formada por 21 (vinte e um) parlamentares titulares e 21 (vinte e um) suplentes. Deste total de 42 (quarenta e dois) parlamentares, a Frente Parlamentar da Agropecuária (FPA) conta com 9 (nove) membros como titulares e 7 (sete) enquanto suplentes; já a Frente Parlamentar de Apoio aos Povos Indígenas conta com 2 (dois) titulares e 2 (dois) suplentes.

Assim, a FPA soma um total de 16 (dezesseis) membros que atuam a favor da PEC215, enquanto a de Apoio aos Povos Indígenas possui 4 (quatro). Em suma, dos 21 (vinte) e um que compõem a Comissão, 10 (dez) são titulares e não fazem parte de nenhuma das duas Frentes Parlamentares. Para que a PEC215 seja aprovada pela Comissão Especial é necessário que 11 (onze) dos membros titulares votem a favor, ou seja, a FPA só precisaria de mais um voto para conseguir a aprovação da PEC 215 na citada Comissão. Aliás, algo que aconteceu em 27 de outubro de 2015, com 21 (vinte e um) votos contra zero. A falta de votos contra ocorreu devido a uma manifestação que fez com que alguns parlamentares se ausentassem, como foi noticiado pelo próprio site de notícias da Câmara:

Deputados de PT, PCdoB, PV, Psol e Rede se manifestaram contra a PEC e, em protesto, se retiraram da reunião antes da votação. Houve divisão de posições no PSB, apesar do encaminhamento oficial contrário à matéria. Os demais partidos com representação na comissão especial aprovaram o texto e comemoraram o resultado (CAMARA 2017: s/p).

Como vimos, este mapeamento acerca do posicionamento dos parlamentares e membros da Comissão mostra que as Bancadas/Frentes Parlamentares ${ }^{11}$ são transpartidárias, com os interesses que soam a manutenção dos privilégios (de poucos) no Brasil. No que antes expusemos como "rede política" (OLIVEIRA, 2007), bem como, dos entrelaçamentos de interesses entre as bancadas (ALMEIDA, 2017) ${ }^{12}$.

\footnotetext{
${ }^{11}$ É importante destacar que nem toda Bancada é uma Frente Parlamentar, mas algumas Bancadas se tornam Frentes Parlamentares, como o caso da Bancada Ruralista, que forma atualmente a Frente Parlamentar da Agropecuária. Já o termo "Bancada" pode se referir a grupos de um mesmo Estado/Região, de um mesmo partido, ou grupos com interesses em comum que compõem o Congresso, mas que não necessariamente se institucionalizam (de acordo com as regras citadas em anterior nota de rodapé).

${ }^{12}$ Tanto o é que um mesmo parlamentar pode compor mais de uma bancada e ao mesmo tempo compor mais de uma Frente Parlamentar.
} 
(...) No fim das contas, no lugar de uma constituição pluripartidária o que se vê nas comissões (que interessam a segmentos setorizados) são composições que apontam para partidos únicos, como: o partido do setor rural, o do setor religioso, o do setor empresarial, o das mineradoras etc. Foi, por exemplo, essa a estratégia utilizada pela bancada evangélica para apossar-se da Comissão de Direitos Humanos e Minorias da Câmara (CDHM), quando logrou emplacar um pastor fundamentalista como seu presidente, em 2013(CAPIBERIBE \& BONILLA 2015: 296).

Por isso, por mais que haja uma tendência de membros de partidos com posicionamento (ao menos teoricamente) de "esquerda/centro-esquerda" atuarem a favor das causas indígenas e, de membros de partidos de "direita" a favor do agronegócio, isso não é uma regra. Podemos citar dois casos para ilustrar: o deputado Hildo Rocha do PMDB-MA faz parte da Frente Parlamentar de Apoio aos Indígenas, junto a ele há mais 20 (vinte) membros do PMDB; Evandro Gussi, deputado pelo PV-SP é membro da Frente Parlamentar da Agropecuária, havendo também mais 2 (dois) deputados do PV como membros. Mesmo que cause certo estranhamento alguém do Partido Verde - cujo foco principal, inclusive nomeando o partido, é a questão pró meio ambiente - apoiar o agronegócio guiado por um processo de produção que vai de encontro à sustentabilidade, podemos a partir disto notar duas questões. A primeira é a de que há uma "flexibilidade ideológica partidária" que transversaliza tal discussão, quiçá (também) face à rede política e seus interesses a salvaguardar, e a segunda é a de que também pode ser uma estratégia na capilarização do objetivo que os move, como aponta Sarney Filho:

Há outros casos curiosos. Apesar de comandar o grupo ambientalista e ser adversário dos ruralistas, o PV conta com dois parlamentares na bancada ligada ao agronegócio. "Essa é uma estratégia nova do partido. Precisamos ter gente nossa lá para defender nossos interesses e ser uma ponte. Mas na hora de votar, há coesão na bancada", afirma o deputado Sarney Filho (PV-AM), presidente da Frente Parlamentar Ambientalista (SENADO 2017: s/p).

Assim, as Frentes Parlamentares enquanto agrupamentos suprapartidários conseguem uma maior potencialidade para atuar em prol de seus interesses, não apenas pela capilaridade partidária, como também por se aliarem, estabelecendo conexões com outras Frentes entre partidos distintos. Observando esta capilaridade, as antropólogas Oiara Bonilla e Artionka Capiberibe tecem críticas mostrando o quanto este sistema causa desequilíbrio entre representatividade e a vontade popular: 
Ora, se as bancadas setorizadas são conhecidas e seus membros nominados, como prova a institucionalização das "Frentes", isso deveria reger os processos de ocupação de espaços dentro de um Congresso que visasse à distribuição proporcional e heterogênea de forças (CAPIBERIBE \& BONILLA 2015: 298).

Tal movimentação também pode ser visualizada como exemplo no processo de tramitação da PEC215, pois como apontado, o deputado Luiz Couto do PT foi o primeiro relator da CCJ da PEC contrário à sua aprovação, sendo também membro da Frente Parlamentar em Apoio aos Indígenas. Posteriormente, de novo a tramitação da PEC foi rejeitada, mas logo em seguida aprovada na CCJ cujo relator foi Geraldo Pudim do PMDB.

Como exercício de capilaridade é preciso ainda reconhecer que os sujeitos também (re)produzem isso, tal como Reinaldo Azambuja que é emblemático. Azambuja se caracteriza enquanto um agente inserido em várias esferas de poder, ocupando o cargo de governador de MS (Mato Grosso do Sul), dono de propriedades rurais, membro da bancada ruralista, apoiador também da Acrissul, bem como, membro da Comissão Especial da PEC215. Observemos esta quase "onipresença" de Azambuja com relação à pluralidade de espaços relativos às diversas esferas de poder nas quais ele ocupa como disparador de sua maior capilaridade.

A partir do exemplo, mergulhemos mais nesta capilaridade das relações estabelecidas pelos sujeitos próximos à tramitação da PEC215. Visualizemos abaixo duas tabelas que apontam para algumas contextualizações dos sujeitos que participaram mais ativamente produzindo documentos - da tramitação da PEC215.

Tabela 2. Atuação dos sujeitos nas Bancadas/Frentes

\begin{tabular}{|c|l|}
\hline \multicolumn{1}{|c|}{ Parlamentares } & \multicolumn{1}{c|}{ Bancadas } \\
\hline \multirow{2}{*}{ Edmilson Rodrigues $P S O L-P A$} & $\begin{array}{l}\text { Frente Parlamentar: de Defesa aos Direitos } \\
\text { Humanos; pela Regularização Fundiária; pelo } \\
\text { Controle de armas, pela vida e paz; Franco } \\
\text { Montoro em Defesa do Parlamentarismo. }\end{array}$ \\
\hline Erika Jucá Kokay PT-DF & $\begin{array}{l}\text { Frente Parlamentar: em Apoio aos Povos } \\
\text { Indígenas; Defesa aos Direitos Humanos. }\end{array}$ \\
\hline \multirow{2}{*}{ Glauber Braga PSOL-RJ } & $\begin{array}{l}\text { Frente Parlamentar: de Defesa aos Direitos } \\
\text { Humanos; em Apoio aos Povos Indígenas; pelo } \\
\text { Controle de armas, pela vida e paz. }\end{array}$ \\
\hline Janete Capiberibe $P S B-A P$ & $\begin{array}{l}\text { Frente Parlamentar: em Apoio aos Povos } \\
\text { Indígenas e de Defesa aos Direitos Humanos. }\end{array}$ \\
\hline \multirow{2}{*}{ Nilson Leitão $P S D B-M T$} & $\begin{array}{l}\text { Frente Parlamentar: da Agropecuária; de Defesa } \\
\text { aos Direitos Humanos; de Defesa da Vida e da }\end{array}$ \\
& $\begin{array}{l}\text { Família (contra o aborto); em Apoio aos Povos } \\
\text { Indígenas; pelo Controle de armas, pela vida e }\end{array}$ \\
\hline
\end{tabular}




\begin{tabular}{|c|c|}
\hline & paz. \\
\hline Osmar Serraglio $P M D B-P R$ & $\begin{array}{l}\text { Frente Parlamentar: Evangélica do Congresso } \\
\text { Nacional; Defesa da Vida e da Família (contra o } \\
\text { aborto); Franco Montoro em Defesa do } \\
\text { Parlamentarismo; Agropecuária; Ambientalista; } \\
\text { pela Competitividade da Cadeia Produtiva do } \\
\text { Setor Químico, Petroquímico e de Plástico } \\
\text { (exploração privada do petróleo); pelo Controle } \\
\text { de armas, pela vida e paz; Municipalista para o } \\
\text { biênio 2015/16. }\end{array}$ \\
\hline Sarney Filho $P V-M A$ & $\begin{array}{l}\text { Frente Parlamentar: Mista da Família e Apoio à } \\
\text { Vida (contra o aborto); de Defesa aos Direitos } \\
\text { Humanos; de Apoio aos Povos Indígenas; pelo } \\
\text { Controle de armas, pela vida e paz; Frente } \\
\text { Parlamentar Evangélica do Congresso Nacional. }\end{array}$ \\
\hline Luiz Couto $P T-P B$ & $\begin{array}{l}\text { Frente Parlamentar: de Defesa aos Direitos } \\
\text { Humanos; em Apoio aos Povos Indígenas; Franco } \\
\text { Montoro em Defesa do Parlamentarismo; pelo } \\
\text { Controle de armas, pela vida e paz. }\end{array}$ \\
\hline
\end{tabular}

Fonte das informações: Site da Câmara.

Como já abordado, uma bancada quando institucionalizada compõe o que se chama de "frente parlamentar". Assim, um mesmo sujeito pode fazer parte de mais de uma frente ao mesmo tempo, de acordo com seus interesses e as estratégias suprapartidárias de capilaridade.

A tabela acima traz a relação dos sujeitos já destacados enquanto produtores de documentos anexados ao trâmite da PEC $215^{13}$, porém, com exceção de dois: Almir Morais Sá, propositor da PEC215 e Geraldo Pudim, relator da CCJ. A ausência destes dois deputados na tabela é devido ao fato de ambos não terem sidos reeleitos recentemente, sendo que o último mandato foi de Almir Sá (PPB) abrangendo o período dos anos de 2007-2011 como deputado federal de Roraima e, o de Geraldo Pudim que atuou como vice-prefeito na cidade de Campos dos Goytacazes/RJ, pelo PDT de 2001 a 2004, antes de se filiar ao PMDB. Mais à frente veremos com detalhes os mandatos dos outros deputados aqui citados.

Voltemos à tabela 2, na qual é possível observar algumas constantes. De certa forma, como o esperado, os votantes contra a PEC215 - Kokay, Rodrigues, Braga, Capiberibe e Sarney Filho-, além de Couto que votou contra na CCJ, fazem parte de bancadas similares, como a ambientalista, a de apoio aos indígenas e a dos direitos humanos. Já Osmar Serraglio e

\footnotetext{
${ }^{13}$ Os relatórios são os documentos mais importantes de uma PEC e os votos em separado aqui analisados são documentos que sinalizam argumentos contra os relatórios, sendo interessantes para a análise dos contra discursos por mais que não tenham uma influência tão profunda na PEC. Isto porque foram poucos ao longo de sua tramitação, os contrários à sua existência.
} 


\section{Nanduty}

ISSN:2317-8590

Nilson Leitão que representam figuras pró PEC215, dentre as bancadas que fazem parte, encontram-se também em algumas mais conservadoras, como a bancada evangélica e a em defesa da família e pela vida, que é contra o aborto. O destoante em meio a estas é Sarney Filho, que apesar de ser uma figura contra a PEC215, também participa destas duas bancadas mais conservadoras, o que pode vir a ser uma estratégia, inclusive pelo retrospecto familiar da influência e circulação de seu pai, o ex-presidente da República, José Sarney ${ }^{14}$.

Há ainda três pontos interessantes a serem analisados. O primeiro deles é o fato do presidente da Comissão Especial da PEC215, Nilson Leitão, fazer parte da bancada de apoio aos indígenas ao mesmo tempo em que é presidente da frente parlamentar da agropecuária (FPA). Tal fato não deve ser interpretado como uma mera contradição, pela evidência de que ambas as bancadas defendem posições opostas, reforçando a capilaridade estratégica por parte da bancada ruralista, como antes sugerido. Outro ponto interessante e semelhante é a posição de Serraglio, que apesar de não fazer parte da bancada de apoio aos indígenas e nem da dos direitos humanos, faz parte da bancada ambientalista ao mesmo tempo em que é da bancada da agropecuária. Mais uma vez bancadas que costumam apresentar posições opostas. Esta estratégia, que como foi citada é seguida pelo PV, não é bem vista por outros partidos, tal $\begin{array}{llllll}\text { como } & \text { P } & \text { PSOL } & \text { (Partido }\end{array}$

O PSOL, sigla de esquerda que defende o Estado laico e é porta-voz dos direitos LGBT, mas conta com um deputado que participa das bancadas evangélica e da bala. "O deputado Cabo Daciolo (RJ) está suspenso do partido e sendo julgado no conselho de ética", diz o deputado Ivan Valente (PSOL-SP). "Somos contra participar, porque essas frentes, bala, ruralista e evangélica, agem de forma articulada." (SENADO 2017: s/p).

O terceiro ponto é a posição de Sarney Filho, tanto pró ambientalismo quanto causas indígenas, que diferente dos outros dois casos, apresenta atuação considerada inusitada, pois ele pertence a uma família que possui propriedades rurais e de certa maneira soma na bancada dos parentes, a mais populosa em nosso legislativo:

\footnotetext{
${ }^{14}$ Hipótese que alimentamos graças a pesquisas como as de Ricardo Costa de Oliveira (2007) que corroboram as redes de política pautadas no parentesco.
} 


\section{Nanduty}

ISSN:2317-8590

Levantamento da Revista Congresso em Foco revela que pelo menos 319 deputados (62\%) e 59 senadores (73\%) têm laços de sangue com outros políticos. Há parlamentares com sobrenomes associados nacionalmente à política, como Maia, Calheiros, Cunha Lima, Caiado, Barbalho e Magalhães, outros de influência regional e aqueles que inauguraram essa tradição. Os números são tão expressivos que fazem o Brasil superar nesse quesito a Î́ndia e sua conhecida sociedade de castas. Pesquisa publicada em 2011 pelo historiador britânico Patrick French mostra que $28 \%$ das cadeiras da Câmara indiana eram ocupadas por deputados com políticos na família (CONGRESSO EM FOCO, 2018: s/p).

Esse cenário reflete o teor nepotista da nossa política, com o poder político estruturado e centrado em elites. Sob tais moldes, a política acaba sendo como uma herança que passa de “de pai para filho". É importante lembrar que esta "espécie de herança colonial” é bastante nociva à democracia, como explica Ricardo Costa de Oliveira em entrevista ao jornal online Gazeta do Povo (GAZETA DO POVO, 2018).

O nepotismo é um sintoma de instituições políticas frágeis, cuja rede de favores de parentesco resume a política em um jogo de interesses pessoais, e é ainda uma prática que vem cada vez mais aumentando. Assim, o nepotismo é um problema tanto por impossibilitar uma renovação de ideias e interesses, quanto pela tendência à corrupção e clientelismo que gera. Retenhamos este dado relativo ao nepotismo e ao fazer política entre parentes como intrínsecos ao modus operandi em terras brasilis, haja vista a tendência de entrelaçamento das bancadas mais populosas (ruralista, empreiteiras, evangélica, empresarial, de parentes) no Congresso Nacional brasileiro.

Continuemos observando as tabelas a seguir sobre a biografia dos sujeitos envoltos na PEC 215. 


\section{Nanduty}

ISSN:2317-8590

Tabela 3. Mapeamento do propositor e relatores das CCJs

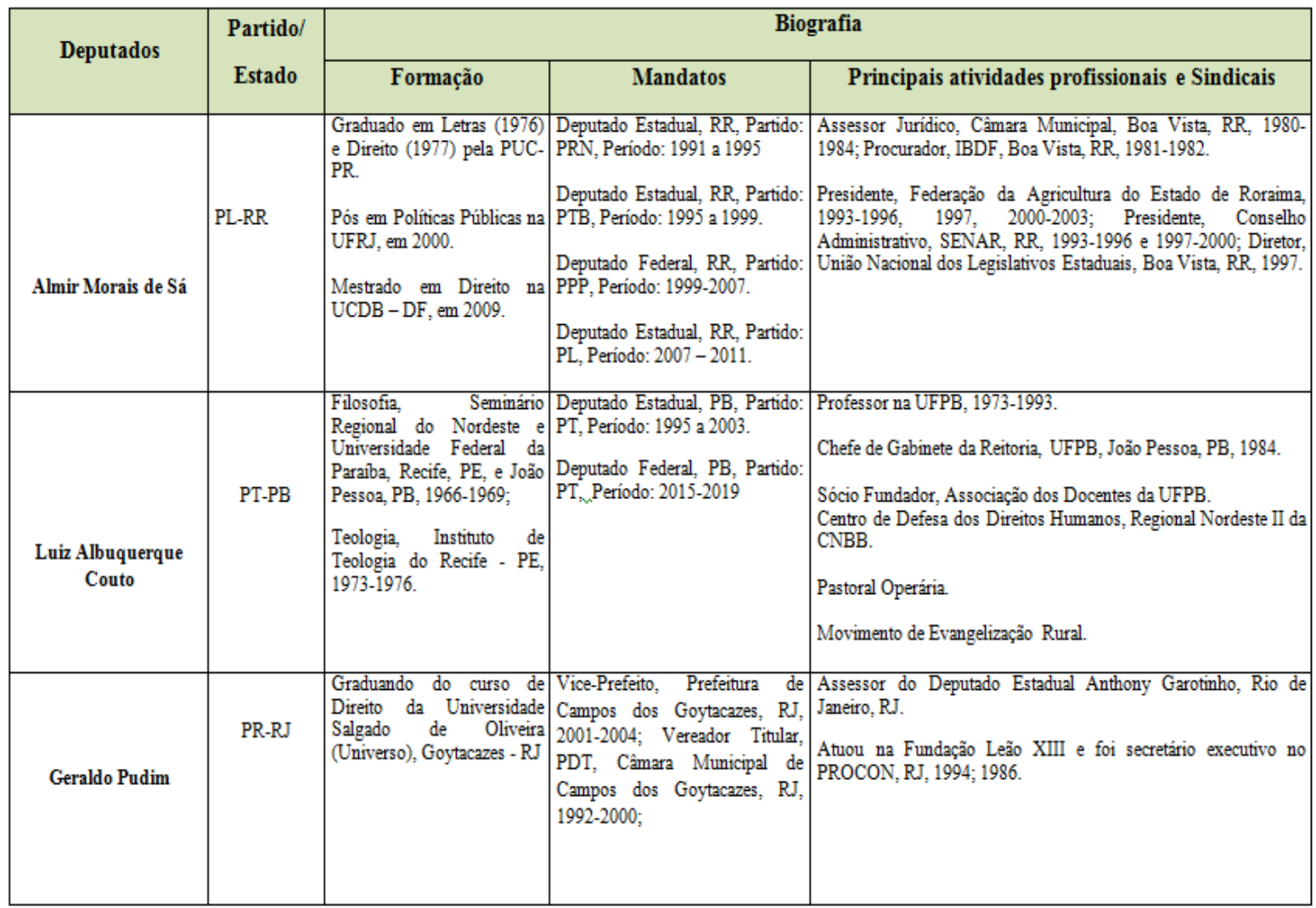

Fonte das informações: Site da Câmara.

Tabela 4. Mapeamento do presidente e do relator da Comissão Especial da PEC215

\begin{tabular}{|c|c|c|c|c|}
\hline \multirow{2}{*}{ Deputados } & \multirow{2}{*}{$\begin{array}{l}\text { Partido/ } \\
\text { Estado }\end{array}$} & \multicolumn{3}{|c|}{ Biografia } \\
\hline & & Formação & Mandatos & Principais atividades profissionais e Sindicais \\
\hline Osmar Serraglio & PMDB-PR & 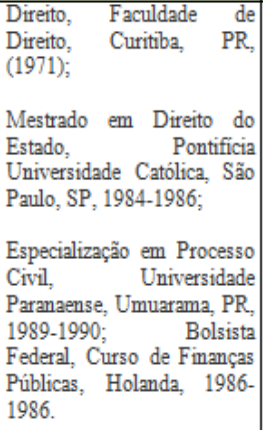 & $\begin{array}{l}\text { Deputado Federal, 1999-2019, } \\
\text { PR, PMDB. } \\
\text { Vice-Prefeito, UmuaramaPR, } \\
\text { Partido: PMDB, Periodo: } 1993 \text { a } \\
1996\end{array}$ & $\begin{array}{l}\text { Assessor Jurídico, Prefeitura, Nova Olímpia, PR, 1988-1988; } \\
\text { Assessor Jurídico, Prefeitura, Japurá, PR, 1997-1997; Assessor } \\
\text { Juridico, Prefeitura, São Jorge do Patrocínio, PR, 1997-1997; } \\
\text { Assessor Jurídico, Prefeitura, Foz do Iguaçu, PR, 1997-1997; } \\
\text { Assessor Jurídico, Prefeitura, Umuarama, PR, 1993-1993; } \\
\text { Assessor Jurídico, Prefeitura, Guaíra, PR, 1993-1993; Assessor } \\
\text { Jurídico, Prefeitura, Iporã, PR, 1993-1993; Assessor Jurídico, } \\
\text { Prefeitura Municipal, Mariluz, PR, 1984-1984; Diretor, } \\
\text { Faculdade de Direito, Universidade Paranaense, Umuarama, } \\
\text { PR.1987-1987; Professor, Direito Administrativo, Pontificia } \\
\text { Universidade Católica, São Paulo, SP, 1980-1986. } \\
\text { Presidente, Associação dos Professores, Umuarama, PR, 1973- } \\
\text { 1975; Secretário, Subseção da OAB, Umuarama, PR, 1977-1992. } \\
\text { Empresário, dono de construtora e imobiliária. }\end{array}$ \\
\hline Nilson Leitão & PSDB-MT & $\begin{array}{l}\text { Técnico em Contabilidade, } \\
\text { Escola Estadual Nilza de } \\
\text { Oliveira Pipino, Sinop, MT, } \\
1990 .\end{array}$ & $\begin{array}{l}\text { Deputado Federal, 2011-2015, } \\
\text { PR, PSDB. } \\
\text { Vereador, Sinop/MT, Partido: } \\
\text { PSDB, Periodo: 1997 a 1999, } \\
\text { Constituinte Deputado Estadual, } \\
\text { CuiabáMT, Partido: PSDB, } \\
\text { Periodo: 1999 a 2000, } \\
\text { Constituinte Prefeito, Sinop/MT, } \\
\text { Partido: PSDB, Periodo: } 2001 \text { a } \\
\text { 2004 Prefeito, Sinop } / M T \text {, } \\
\text { Partido: PSDB, Periodo: } 2005 \text { a } \\
2008 \text { S }\end{array}$ & Empresánio \\
\hline
\end{tabular}




\section{Nanduty}

ISSN:2317-8590

Fonte das informações: Site da Câmara.

Tabela 5. Mapeamento dos sujeitos de posicionamento contra a PEC215

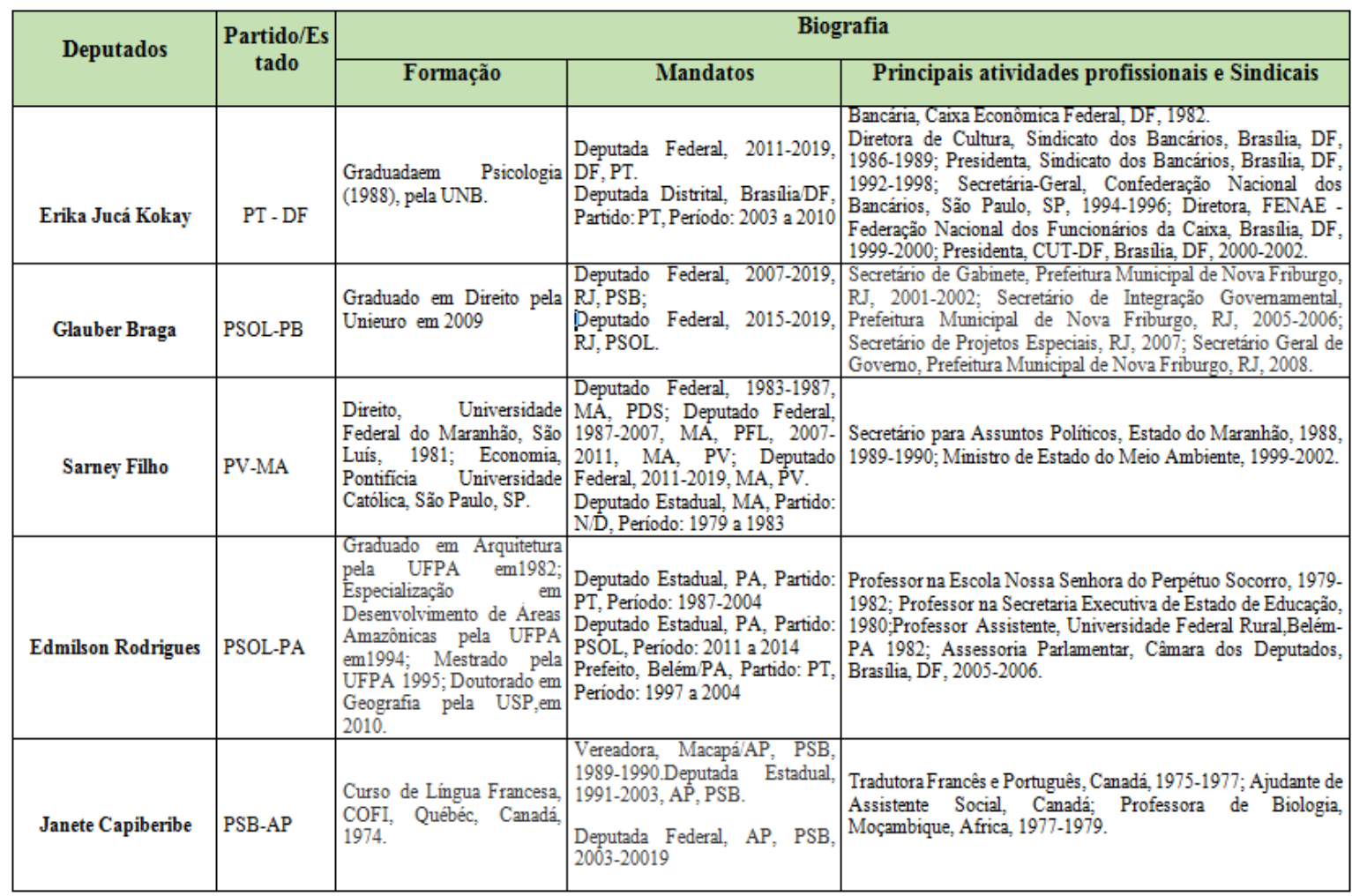

Fonte das informações: Site da Câmara.

Como foi apresentado nas tabelas 3,4, e 5 acerca de alguns aspectos biográficos, podemos traçar pontos em comum entre estes sujeitos. Comecemos observando a questão profissional. Todos os citados, com exceção de Janete Capiberibe e Nilson Leitão, tem ensino superior completo, além disso, nos que apresentam ensino superior há prevalência da graduação em Direito - algo similar ao que nos estruturou em tempos de primeira república (SCWHARCZ 1993).

Cabe sublinhar que Nilson Leitão é presidente da Comissão Especial da PEC215, cujo objetivo é uma análise mais aprofundada do conteúdo da mudança constitucional, ou seja, mesmo não tendo o conhecimento "técnico" na área do direito (constitucional) ele é uma das peças chaves na questão. O referido congressista não apresenta formação específica, a despeito de lidar com uma posição proeminente dentro da tramitação da PEC 215. Portanto, de significativa responsabilidade. 
Ainda sobre a figura de Nilson Leitão é importante acrescentar mais outras informações. No ano de 2015, Leitão foi alvo de uma investigação através de escutas telefônicas pelo MPF - Ministério Público Federal, juntamente com o relator Osmar Serraglio (ministro da Justiça do/no "governo" Temer) sobre o envolvimento de invasão de territórios indígenas já demarcados:

A Justiça Federal do Mato Grosso decidiu enviar para o Supremo Tribunal Federal (STF) o processo que investiga possível envolvimento dos deputados federais Osmar Serraglio (PMDB-PR) e Nílson Leitão (PSDB-MT), num esquema, segundo o Ministério Público Federal em Mato Grosso, de invasão de terras indígenas e de arrecadação de $\mathrm{R} \$ 30$ mil para direcionar parecer na comissão da Câmara que trata de demarcação de territórios (O GLOBO, 2018a: s/p).

Além deste caso, ainda no ano de 2015, Nilson Leitão foi alvo de outra investigação pelo MPF, a saber: ele seria investigado por superfaturamento na execução de obras de pavimentação e drenagem em trecho urbano da BR-163, no período enquanto era prefeito de Sinop/MT (SOCIOAMBIENTAL 2017). Apesar de todas as investigações, nenhum dos dois deputados chegou a ser afastado da Comissão da PEC215.

Tratando dos demais componentes da comissão, com exceção de Glauber Braga e Luiz Couto, todos os outros respondem a processos judiciais, seja pelo Supremo Tribunal Federal (STF), Tribunal Regional Federal (TRF) e/ou pelo Tribunal Superior Eleitoral (TSE). Vejamos mais especificamente: Érika Kokay é alvo de inquérito pelo STF por crimes contra a ordem tributária $(\mathrm{G} 1,2018 \mathrm{~b})$, corrupção ativa e lavagem de dinheiro; Sarney Filho foi condenado a pagamento de multa por prática de conduta vedada pelo TRE-MA (O GLOBO, 2018b); Edmilson Rodrigues foi condenado por impropriedade administrativa e por interromper repasse de verbas pelo TRF (VEJA, 2018); Janete Capiberibe e o marido, senador João Capiberibe, tiveram os mandatos cassados pelo TSE por captação ilícita de votos nas eleições de 2002 (O GLOBO, 2018c). Reiteramos que dados sobre Almir Sá e Geraldo Pudim não aparecem aqui, pois ambos não foram eleitos recentemente.

Retomemos as tabelas. Outro ponto que deve ser sublinhado é que de maneira geral todos acumulam vários mandatos enquanto deputados estaduais, deputados federais, senadores e prefeitos, proporcionando uma capilaridade maior, inclusive, entre o Executivo e o Legislativo. Com relação às profissões, além dos cargos públicos, destaca-se também a atuação enquanto professores universitários. Ademais, os dois únicos que não se enquadram 


\section{Nanduty}

ISSN:2317-8590

(somente) nesta lógica de cargo público e professor estão Nilson Leitão e Osmar Serraglio, pois ambos são empresários.

Cabe ainda nos atentarmos a outra informação presente na tabela 3 , referente à atuação de Almir Moraes Sá, pois este foi presidente da Federação da Agricultura do Estado de Roraima, estado no qual foi demarcado o território indígena Raposa Serra do Sol. O caso de Raposa do Sol foi um processo de demarcação que demorou anos, envolveu indígenas, posseiros e ruralistas, para além de ter se desenvolvido juridicamente pelo e no STF, levando a tantos debates que, nos documentos do trâmite da PEC215, o mesmo é constantemente citado. No período de desenvolvimento jurídico da Raposa Serra do Sol, Almir Sá enquanto presidente da Federação de Agricultura de Roraima chegou a ser entrevistado acerca de sua posição perante o caso. Vejamos um excerto da notícia no sítio do jornal Estadão:

Ao comentar o assunto em uma entrevista, o presidente da Federação da Agricultura de Roraima, Almir Morais Sá, disse recentemente que a Igreja, sob "a orientação de um bispo chamado d. Aldo Mongiano", orientou os indígenas sobre a demarcação, além de propagar entre eles conceitos de "tradição, povo, cultura" (ESTADÃO, 2017: s/p).

Destaquemos os discursos de "culpabilização" da Igreja Católica perante a situação indígena, como se esta incitasse a quebra de uma "harmonia" existente entre indígenas e ruralistas, bem como serem os indígenas passivos em termos de agenciamento, conforme falas de representante do bispado. O que para os ruralistas significa(ria) que "indígena bom" é aquele que trabalha na terra do fazendeiro e não reivindica seu direito constitucional à terra tradicional, tal como relatou Roseli Ruiz ${ }^{15}$ em entrevista ao sítio do jornal El País no ano de 2015. Aliás, período no qual ocorreram conflitos no município de Antônio João, no Mato Grosso do Sul, com mais mortes corriqueiras de indígenas.

Há muitos anos, uma família comprou uma grande área para fazer fazenda no Paraguai. Eles precisavam tirar os índios de lá e doaram um pedaço de terra. Nessa área, morava a família de um índio chamado Alziro Vilhalva, que trabalhava em uma fazenda ao lado da nossa. Um dia, ele ganhou do dono da fazenda uma área para viver mais perto do trabalho [que se tornou a Vila Campestre]. Em 1970, foi criado o CIMI aqui e um antropólogo começou a visitar os lugares onde tinha índio. Todo o lugar tinha índio. Os índios sempre trabalharam na fronteira, sempre procuravam serviço nas fazendas, isso não é novidade para ninguém (EL PAÍS, 2017: s/p).

\footnotetext{
${ }^{15}$ Fazendeira, "militante" ruralista e presidenta do sindicato rural de Antônio João/MS.
} 
Percebamos como a engrenagem perversa do capitalismo selvagem, faz com que Roseli Ruiz ligue o vínculo dos indígenas com a terra - instituidora de seus corpos (afinal são partes de um todo ${ }^{16}$ ) - de maneira resumida à força de trabalho e nada mais. Em segundo momento da entrevista, Roseli Ruiz completa:

Eu era conhecida como a Roseli dos índios! Um índio era picado de cobra aqui, eu botava na minha camionete e levava para o hospital. Todo mundo sabe dessa história. Desde que eu casei, Natal, Dia das Crianças e Páscoa, eu fazia festa para eles. Eu tenho foto da minha filha pequena, vestida de Papai-Noel, com a camionete cheia de brinquedo, distribuindo pros indinhos. A gente distribuía lá, na Vila Campestre, e depois vinha para a cidade. Todo mundo sabe disso. Tem tudo registrado. Mas em 1998, dia 21 de dezembro, um índio ligou pra gente e falou que ia ter invasão da nossa fazenda. A gente nunca tinha ouvido falar de invasão e nem que índios queriam a nossa terra. Nós éramos amigos deles, convivíamos na maior tranquilidade do mundo (EL PAÍS 2017: s/p).

Como podemos notar este discurso contra a igreja católica é "figurinha repetida" nos enunciados de ruralistas, mas nunca é "velha" o suficiente para ser esquecida, tanto que culminou na CPI do CIMI, como foi citado anteriormente. E de maneira a camuflar a violência armada na região de Mato Grosso do Sul propagada por fazendeiros, percebe-se que "a amizade" outrora havida entre eles e os indígenas se torna o elo perdido em meio à narrativa da ruralista.

\section{Das reticências finais (...)}

Se as categorias "amizade" e "parente" podem ser férteis em ambos os contextos, de indígenas e não indígenas do sul de Mato Grosso do Sul, inclusive para a análise do cenário de guerra disparada cotidianamente face às questões que tocam as terras tradicionais indígenas ${ }^{17}$, por agora apenas reforçamos o compartilhar dos dados que suscitam eventuais entrelaçamentos da bancada ruralista com outras, como a de parentes, como a empresarial, como a evangélica, como a de empreiteiras/construtoras. Abaixo segue esquema referente ao quantitativo de congressistas nas principais bancadas da Câmara:

\footnotetext{
${ }^{16}$ Diferentemente de nós, os brancos ou Karaí.

${ }^{17}$ No massacre de Haximu a maneira como "a amizade" pelos garimpeiros é gestada no e para o ataque dos Yanomami nos parece importante para pensarmos estas relações conflituosas (KOPENAWA \& ALBERT, 2015: 574). No ataque de Caarapó em 2016, dezenas de fazendeiros cercaram e atacaram os Kaiowá e Guarani (GUIMARÃES, 2016). Para além, interessante torna-se considerar como se deram/dão as práticas (incluindo as que soaram racistas) dos habitantes da cidade de Caarapó no tratamento dispensado aos indígenas após o ataque (BECKER, OLIVEIRA \& MARTINS, 2016).
} 


\section{Nanduty}

ISSN:2317-8590

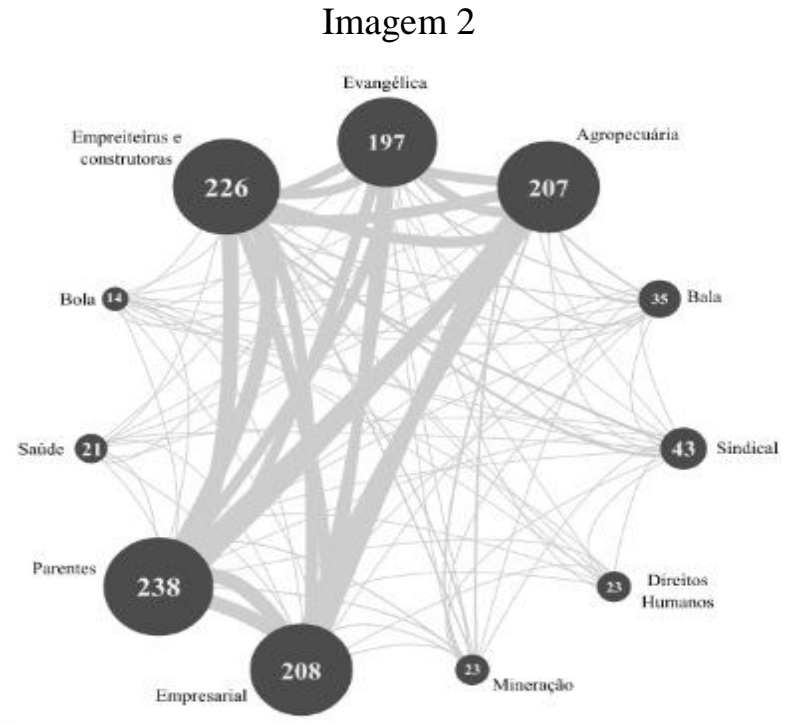

Fonte: Congresso em Foco (2018)

Como vimos ao longo de nosso ensaio, a capilaridade é uma característica desse contexto de rede política, tanto no tocante à forma como esses sujeitos estabelecem relações dentro das bancadas, como nos discursos de interesses e maneiras de (re)produção destes.

A imagem acima das bancadas mostra que são cinco as principais: Parentes, Empreiteiras/Construtoras, Agropecuária, Empresarial e Evangélica. Cabe relembrar, tal como destacamos anteriormente, que um mesmo parlamentar tende a compor mais de uma bancada. Por isso, como explica Dalson Britto (CONGRESSO EM FOCO, 2018), dentro deste contexto a análise de comportamentos e influências desses agentes representa um desafio e, por vezes, até parecem contraditórias. Afinal as influências correspondem a questões como: ideologia, trajetória, base eleitoral e as alianças com diversas legendas. Estes quatro pontos podem apresentar diferentes pesos em termos de valores. Acompanhemos ilustrações de Britto:

Imagine a situação de um deputado que tem que escolher entre votar de acordo com a indicação do seu líder, agradar à sua base e ao mesmo tempo contemplar os interesses dos grupos que financiaram sua campanha. É de se esperar alguma consistência ideológica nas votações; no entanto, se for para escolher entre a fidelidade às diretrizes ideológicas do partido e a lealdade aos financiadores, eu acredito que os parlamentares escolham a fonte de recursos. Afinal, campanhas eleitorais custam caro e alguém tem que arcar com esse custo. Lembrando: "não existe almoço grátis"” (CONGRESSO EM FOCO, 2018: s/p). 


\section{Nanduty}

ISSN:2317-8590

Neste sentido, interessante se tornam as palavras, uma vez mais, do pesquisador Ricardo Costa de Oliveira (2007: 150), quem durante anos investigou a perpetuação no governo do Estado do Paraná em cargos de poder no cenário político: "a pobreza, a carência e a miséria também podem ser consideradas produtos da falta de políticas sociais do Estado. Pobreza e riqueza, poder e carência são diferentes lados da mesma moeda social, econômica e política”. E mais: talvez possamos inferir que os entrelaçamentos entre os parlamentares da bancada ruralista e entre as principais bancadas e respectivos parlamentares, suscitam o tom de "partido único" e/ou de transpartidarismo destas movimentações.

Sublinhamos, nas entrelinhas, o quão o movimento rizomático que envolve a e é disparado pela PEC 215 não se resume apenas à Bancada Ruralista, mas também à articulação do Movimento Indígena. Em especial, porque mesmo sem se fazer representar no Congresso, o Movimento Indígena se articula de forma capilarizada, conseguindo em alguns casos interferir e re-existir no próprio trâmite da PEC 215. Em dezembro de 2014, por exemplo, foi cancelada uma das votações da PEC 215 graças à manifestação de indígenas na Câmara (NOTICIASR7, 2015: s/p).

Para além, ao longo desses dezoito anos de trâmite da PEC 215, indígenas se articulam de maneira também rizomática, seja com bloqueios de várias rodovias no país para chamar a atenção da questão de demarcação de terras e a PEC 215; seja com manifestações na Câmara; seja através de mídias e redes sociais. Podemos notar, assim, que a capilaridade do movimento indígena é uma forma de (re)existência, pois mesmo em meio a tantas precariedades, os indígenas conseguem fazer oposição e seguem lutando por um direito que já lhes é garantido, porém não é respeitado e ainda há risco de lhes ser retirado que é o direito as suas terras tradicionais.

\section{BIBLIOGRAFIA}

ABREU, Rafael Rondis Nunes de. 2017. A temática indígena no jornal O Progresso: Dilemas e impasses entre direitos indígenas, Estado e sociedade civil. Dissertação de mestrado em Antropologia, Universidade Federal da Grande Dourados.

AGENCIA BRASIL. 2017. CPI da FUNAI finaliza trabalhos e pede indiciamento de lideranças. In: http://agenciabrasil.ebc.com.br/politica/noticia/2017-05/cpi-da-funaifinaliza-trabalhos-e-pede-indiciamento-de-liderancas. Acessado em 02 de julho de 2018. 
ALMEIDA, Ronaldo de. 2017. A onda quebrada - evangélicos e conservadorismo. Cadernos Pagu, Campinas, n. 50, e175001, 2017 . Available from <http://www.scielo.br/scielo.php?script=sci_arttext\&pid=S010483332017000200302\&lng=en\&nrm=iso>. Acessado em 20 agosto 2018. Epub June 26, 2017. http://dx.doi.org/10.1590/18094449201700500001

BECKER, Simone, OLIVEIRA, Esmael Alves de; MARTINS, Catia Paranhos. 2016. "Onde fala a bala, cala a fala": resistências às políticas da bancada da Bala, do Boi e da Bíblia em Mato Grosso do Sul. Dourados. In: http://www.redehumanizasus.net/94812-ondefala-a-bala-cala-a-fala. Acessado em 19 março 2018.

BECKER, Simone e MORAES, Valentin Ferreira .2017. O (re)torno da "guerra justa" (?): os impactos das propostas da PEC 287 no tocante aos e às indígenas - incluindo da região da Grande Dourados/MS. Revista Publicum de Direito da UERJ. In: http://www.e-publicacoes.uerj.br/index.php/publicum/article/view/29012. Acessado em 10 de janeiro de 2018.

BECKER, Simone; ROCHA, Taís Cássia Peçanha. 2017. Notas sobre a "tutela indígena" no Brasil (legal e real), com toques de particularidades do sul de Mato Grosso do Sul. Revista $d a$ Faculdade Direito UFPR. In: https://revistas.ufpr.br/direito/article/view/49443. Acessado em 24 de junho de 2018.

BOURDIEU, Pierre. 2001. A ilusão biográfica. Usos e abusos da história oral. Rio de Janeiro, Ed. FGV, pp. 183-191.

BUTLER, Judith 2003. Problemas de gênero: feminismo e subversão da identidade. Rio de Janeiro: Civilização.

BUTLER, Judith. 2015. Quadros de Guerra - quando a vida é passível de luto? Rio de Janeiro: Editora Civilização Brasileira.

BUTLER, Judith. 2018. A criminalização do conhecimento. In: https://www.diariodocentrodomundo.com.br/a-criminalizacao-do-conhecimento-porjudith-butler/ . Acessado em 20 de junho de 2018.

CAPIBERIBE, Artionka \& BONILLA, Oiara. 2015. A ocupação do Congresso: contra o quê lutam os indios? Estudos Avançados. In: http://www.scielo.br/scielo.php?script=sci_arttext\&pid=S0103 40142015000100293. Acessado em 21 maio de 2017.

CÂMARA. 2018a. Com protesto de opositores comissão aprova a PEC sobre as terras indigenas. In: http://g1.globo.com/economia/agronegocios/agro-a-industria-riqueza-dobrasil/noticia/2016/10/agronegocio-e-valorizado-em-campanha-da-rede-globo.html Acessado em 21 setembro de 2018. 


\section{CÂMARA. 2018b. Relatório Final CPI CIMI. In:} http://www.camara.leg.br/internet/comissoes/comissoesespeciais/CPI/ANEXOS/MATO\%20GROSSO\%20DO\%20SUL/DOCUMENTO\%20n $\%$ C2\%B017.pdf. Acessado em 07 de setembro de 2018.

CARTA CAPITAL. 2018. Em busca de sobrevivência Temer troca o ministro da Justiça. In: https://www.cartacapital.com.br/politica/em-busca-de-sobrevivencia-temer-troca-oministro-da-justica. Acessado em 02 de julho de 2018.

CONGRESSO EM FOCO. 2018. Congresso, um negócio de família: seis em cada dez parlamentares têm parentes na política. https://congressoemfoco.uol.com.br/especial/noticias/congresso-um-negocio-de-familiaseis-em-cada-dez-parlamentares-tem-parentes-na-politica/. Acessado em 16 de agosto de 2018.

CUNHA, Manuela Carneiro da. 2009. Cultura com aspas. São Paulo: Cosac \& Naify.

DELEUZE, Gilles \& GUATTARRI, Félix. 1995. Introdução: Rizoma, em Mil Platôs: capitalismo e esquizofrenia. vol.1. São Paulo: Editora 34.

EL PAÍS. 2017. "Fazendeira em conflito com indígenas: "Só saio de casa algemada ou morta." In: https://brasil.elpais.com/brasil/2015/09/06/politica/1441494809_661684.html. Acessado em 30 de maio de 2017.

ESTADÃO. 2017. Igreja católica atura por reserva indígena em Roraima. In: http://www.estadao.com.br/noticias/geral,igrejacatolica-atua-por-reserva-indigena-emroraima,365648 . Acessado em 09 de janeiro de 2017.

FPAGROPECUARIA, 2018, Frente Parlamentar da Agropecuária. In: http://www.fpagropecuaria.org.br/ . Acessado em 19 de agosto de 2018.

G1. 2018a. Agronegócio é valorizado em campanha da rede Globo. In: http://g1.globo.com/economia/agronegocios/agro-a-industria-riqueza-dobrasil/noticia/2016/10/agronegocio-e-valorizado-em-campanha-da-rede-globo.html Acessado em 07 de setembro de 2018.

G1. 2018b. STF envia inquérito de Kokay para Justiça do DF. In: https://g1.globo.com/df/distrito-federal/noticia/marco-aurelio-mello-envia-inqueritosde-erika-kokay-para-a-justica-do-df.ghtml. Acessado em 03 de julho de 2018.

GAZETA DO POVO, 2018. "A política vem se tornando um negócio de família no Paraná" In: $\quad$ https://www.gazetadopovo.com.br/vida-publica/a-politica-vem-se-tornandonegocio-de-familia-no-parana-daedg5khe2xep7latvv9o0kem. Acessado em 16 de agosto de 2018. 
GUATTARI, Félix. 1985. A revolução molecular. Pulsações políticas do desejo. $3^{\mathrm{a}}$ edição. São Paulo, Brasiliense.

GUIMARÃES, Thiago. 2016. O polêmico conflito entre índios e fazendeiros que explodiu após "ato final" de Dilma. In: https://www.bbc.com/portuguese/brasil-36538610. Acessado em 23 agosto de 2018.

KOPENAWA, Davi; ALBERT, Bruce. 2015. A queda do céu: palavras de um xamã Yanomami. $1^{a}$ edição. São Paulo, Companhia das Letras.

LANDA, Gabriel. 2018. A construção da imagem dos povos indígenas e produtores rurais nos jornais online da região sul de Mato Grosso do Sul. Dissertação de mestrado em Antropologia, Universidade Federal da Grande Dourados.

LENHARO, Alcir. 1986. "A terra para quem nela não trabalha: a especulação com a terra no Oeste brasileiro nos anos 50”. Revista Brasileira de História, 6 (12): 47-64.

MACEDO, Rayane Bartolini. 2017. Debaixo da terra: uma genealogia cartográfica acerca dos discursos que permeiam as tessituras rizomáticas da PEC 215. Dissertação de Mestrado em Sociologia, Universidade Federal da Grande Dourados.

MBEMBE, Achille. 2016. "Necropolítica". Arte \& Ensaios - Revista do PPGAV/EBA/UFRJ, n. 32, dezembro, pp. 122-151.

MEYER, Luiza Gabriela Oliveira. 2014. Rumo à (des)colonização? O direito de consulta e os seus (ab)usos na Reserva Indígena de Dourados (RID). Dissertação em Antropologia Social, Universidade Federal da Grande Dourados.

NOTÍCIAS R7. 2015. Votação da PEC 215 é cancelada por causa de protesto de índios na Cãmara. In: https://noticias.r7.com/record-news/jornal-da-record-news/videos/votacaoda-pec-215-e-cancelada-por-causa-de-protesto-de-indios-na-camara-16102015. Acessado em 16 de agosto de 2018.

O GLOBO. 2018a. Processo contra relator e vice de comissão sobre terras indígenas chega ao STF. In: //oglobo.globo.com/brasil/processo-contra-relator-vice-de-comissao-sobreterras-indigenas-chega-ao-stf-14832331. Acessado em 07 de setembro de 2018.

O GLOBO. 2018b. TSE mantém o registro da candidatura de Sarney Filho. In: https://oglobo.globo.com/brasil/eleicoes-2010/tse-mantem-registro-da-candidatura-desarney-filho-4989549. Acessado em 16 de agosto de 2018.

O GLOBO. 2018c. TSE cassa registro de Janete Capiberibe no Amapá. In: https://oglobo.globo.com/brasil/eleicoes-2010/tse-cassa-registro-de-janete-capiberibeno-amapa-4988949. Acessado em 16 de agosto de 2018. 
OLIVEIRA, Ricardo Costa de. 2007. "Famílias, poder e riqueza: redes políticas no Paraná em 2007. Sociologias, ano 9, n. 18, jun-dez. Porto Alegre: UFRGS, pp. 150-169.

PIB. SOCIOAMBIENTAL. 2018. População Indígena no Brasil. In: https://pib.socioambiental.org/pt/c/0/1/2/populacao-indigena-no-brasil. Acessado em junho de 2018.

PLANALTO. 2018. Constituição Federal de $1988 . \quad$ In: http://www.planalto.gov.br/ccivil_03/constituicao/constituicaocompilado.htm. Acessado em junho de 2018.

ROLNIK, Suely. 2018. Esferas da insurreição: notas para uma vida não cafetinada. São Paulo: n-1 edições.

SCHWARCZ, Lilia. 1993. O Espetáculo das raças: cientistas, instituições e questão racial no Brasil (1870-1930). São Paulo, Editora Companhia das Letras.

SENADO. 2017. Deputados das bancadas da 'bala, boi e Bíblia' atuam juntos em defesa de interesses próprios e aumentam poder do presidente da Câmara. In: https://www2.senado.leg.br/bdsf/bitstream/handle/id/509963/noticia.html?sequence=1 Acessado em 02 de janeiro de 2017.

SILVA, Mariana Pereira da. 2013. Entre vivências \& narrativas de jarýi - parteiras de Amambai/MS e AIS do posto de saúde Bororó. Dissertação de mestrado em Antropologia, Universidade Federal da Grande Dourados.

SOCIOAMBIENTAL. 2017. Relatório do Grupo de Trabalho destinado a debater a questão das terras indígenas.

In: https://www.socioambiental.org/sites/blog.socioambiental.org/files/nsa/arquivos/relatori o_do_grupo_de trabalho_indios_dep_lincoln_portela_com_sugestoes_aprovados_na_re uniao_macs_final.pdf. Acessado em janeiro de 2017.

UOL. 2018a. "PGR denuncia ministro da agricultura sob acusação de corrupção". In: https://noticias.uol.com.br/politica/ultimas-noticias/2018/05/02/pgr-denuncia-ministroda-agricultura-sob-acusacao-de-corrupcao-ativa.htm Acessado em agosto de 2018.

UOL. 2018b. "O preconceito aumenta a violência contra indios", diz presidente da Funai". In: $\quad$ https://noticias.uol.com.br/politica/ultimas-noticias/2016/01/13/ha-setores-comelevado-preconceito-contra-indios-diz-presidente-da-funai.htm. Acessado em setembro de 2018).

VEJA. 2018. Candidato do Psol em Belém é condenado por impropriedade. In: https://veja.abril.com.br/politica/candidato-do-psol-em-belem-e-condenado/ Acessado em 16 de agosto de 2018. 


\section{Nanduty}

ISSN:2317-8590

VIGNA, Edélcio. 2001. A bancada ruralista: um grupo de interesse. Argumento, Brasília, INESC.

VIVEIROS DE CASTRO, Eduardo. 2016. Sobre a noção de etnocídio, com especial atenção ao caso brasileiro. In: https://www.academia.edu/25782893/Sobre_a_no\%C3\%A7\%C3\%A3o_de_etnoc\%C3 \%ADdio_com_especial_aten\%C3\%A7\%C3\%A3o_ao_caso_brasileiro Acessado em janeiro de 2017.

VIVEIROS DE CASTRO. 2015. "Prefácio - O recado da Mata". In: KOPENAWA, Davi; ALBERT, Bruce. A queda do céu: palavras de um xamã yanomami. $1^{\mathrm{a}}$ edição. São Paulo, Companhia das Letras.

XAVIER, Glauber Rocha. 2015. Senhores da Lei, Donos da Terra": o arauto da bancada ruralista na Câmara dos Deputados (2009-2014).. Estudos Sociedade e Agricultura, vol 23, Rio de Janeiro. 